1966

\title{
Challenge and Response in the Law of Labour Relations
}

Harry W. Arthurs

Osgoode Hall Law School of York University, harthurs@osgoode.yorku.ca

Source Publication:

UBC Law Review. Volume 2, Number 3 (1966), p. 335-360.

Follow this and additional works at: https://digitalcommons.osgoode.yorku.ca/scholarly_works (c) (1) $(9)$

This work is licensed under a Creative Commons Attribution-Noncommercial-No Derivative Works 4.0 License.

\section{Recommended Citation}

Arthurs, Harry W. "Challenge and Response in the Law of Labour Relations." UBC Law Review 2.3 (1966): 335-360.

This Article is brought to you for free and open access by the Faculty Scholarship at Osgoode Digital Commons. It has been accepted for inclusion in Articles \& Book Chapters by an authorized administrator of Osgoode Digital Commons. 


\section{CHALLENGE AND RESPONSE \\ IN THE LAW OF LABOUR RELATIONS}

\section{H. W. ARTHURSt}

Challenge and response in the law are by no means confined to the area of labour relations. In many areas of law, which touch upon controversial social questions, there is a continual and a healthy tension between law and life. Law, after all, is a technique for preserving order and stability in society, for substituting calm and reasoned judgment for passion and violent pursuit of self interest. Necessarily, however, the order and stability which law represents take the form of a prevailing social consensus. Thus, before the law can change, it is necessary for society's thinking to change. Inevitably, then, there is a cultural lag between legal and social values. This lag is accentuated by our few, slow, and clumsy techniques for law reform. As someone has put it, the problem is that judges won't and legislators can't.

The common law, at best, is laboriously built, case upon case, over a period of years. Thus, it is extremely unlikely that the development of a common law doctrine will be much altered once its foundations are laid. Such shifts as do take place are likely to be marginal, and often surreptitious. Moreover, the common law judge can only speak when a litigant brings a case to him. Thus, even if the courts were receptive to change, it might be years before the appropriate occasion arose, especially since the facts of a particular case are crucial in determining its outcome. The common law, in sum, is likely to respond to social challenges with something less than haste. Even this truism ignores the propriety or otherwise of judges deciding fundamental, yet delicate, issues of public policy.

More and more, then, we have turned to the legislatures to solve labour problems. Yet, here again, the law does not automatically change its course to adapt to new challenges. Typically, labour relations legislation is the product of vigorous and belligerent lobbying by each side for a new law with which to club the other into submission. Even if the law is less extreme than

$\dagger$ W. W. Arthurs, B.A., IL. B. (Toronto); IL.M. (Harvard), Associate Professor, Osgoode Hall Law School, Toronto. This article is an adaptation of an address delivered to the Founding Conference of the University of Toronto Centre for Industrial Relations, October 14, 1965. 
its sponsors might have wished, it is unlikely that the loser in this legislative donnybrook will accept the new law in good grace, and will make it work well. It must be emphasized, moreover, that the relationship between life and law, between social challenge and legal response, is one of reciprocity. Just as the law changes slowly to produce new solutions for the industrial relations community, so too the law's impact upon that community produces new problems which in turn demand their own solution.

Yet, the great challenges are external to the law and are produced by the dynamics of industrial relations. Set against the background of a rather rigid and unresponsive legal system, these seem swifter and more urgent. Consider some of the recent developments in the world of industrial relations, and the challenges they must pose to the legal system. Trite indeed it is to observe that our world is ever more rapidly changing in its technology, in its complexity and interdependence. What is less frequently observed is a rapid and profound revolution of our expectations. In international relations, it is no doubt the very magnitude of potential conflict which has produced an earnest (and occasionally successful) search for new techniques of peacekeeping. Not all of these techniques seek to end conflict as it erupts. The vast proliferation of international agencies of aid and collaboration is intended to strike at the very roots of discontent. By assisting the "have-not" countries, the "haves" hope to preserve the peace, while gaining good-will. A less cynical interpretation of events might be that we are finally recognizing our international moral responsibilities. But whether their motives are selfish or noble, we have come to expect more of nations. So, too, with the world of industrial relations. In an increasingly complex economy, caught up in a process of technological change, we are in the midst of a revolution of expectations. Yesterday we were prepared to contemplate strikes as an inevitable adjunct of collective bargaining. Tomorrow, we may no longer let the parties make war. Indeed, even today we are no longer content that industrial strife should be speedily ended. We have begun to anticipate strife, and to eradicate its causes. $^{1}$ Perhaps, indeed, we have begun to introduce a new

1 "Continuous bargaining" experiments have begun in the steel industry, and others, in the United States. In Canada, annual high-level labour-management conferences in the Domtar companies, and the work of the Nova Scotia Insti- 
element of morality into our judgment of how labour and management should behave.

Is our law attuned to these new developments? The answer seems to be negative. Technology changes quickly, yet the parties often freeze their relationships in a collective agreement binding for two or three years - and cannot legally sign an agreement for less than one. ${ }^{2}$ Our problems are constantly more complex, yet our legislative policy is designed to encourage collective bargaining only on the basic issues of wages and working conditions. ${ }^{3}$ Our social and economic units are increasingly interdependent, yet our constitution fragments nation-wide bargaining into provincial patterns, ${ }^{4}$ and our statutes put a premium on the single-union, single-employer bargaining unit. ${ }^{5}$ And finally, our law of labour relations embodies the low expectations, the old morality, of the nineteen thirties and forties. No more is demanded than a minimal and murky statutory duty to "bargain in good faith" and adherence to a judicially-drafted set of Marquis of Queensbury rules for industrial warfare. While an elaborate jurisprudence has developed around the latter, ${ }^{7}$

stute of Public Affairs are two prominent examples of the "new wave" in industrial peacekeeping. See The Status of Labour-Management Cooperation in Canada, 65 IAB. GAZ. 226 (1965).

2 See, e.g., Iabour Relations Act, ONT. REV. STAT. c. 202 (1960), § 39(1); B.C. REV. STAT. c. 205 (1960), \$ 23(1).

3 See, e.g., Labour Relations Act, ONT. REv. STAT. c. 202 (1960), § I(c); B.C. REV. STAT. c. 205 (1960), § 2(1); Industrial Relations and Disputes Investigation Act, CAN. REv. STAT. c. 152 (1952), § 2(1) (d).

${ }^{4}$ Scott, Federal Jurisdiction Over Labour Relations - A New Look, 6 MCGILL L. J. 153 (1960).

5 See, e.g., Pigott Construction, (1965) C.C.H.L.I.R. P. 16,053 (O.L.R.B.). In Ontario, a union may only be certified for a single-employer bargaining unit (Labour Relations Act, ONT. REv. STAT. c. 202 (1960), § \$ 1(1)(a); 5 (1) ), although by a process of voluntary recognition, it may bargain and sign an agreement with an employer association ( $\$ 1$ (I) (c); 38). In British Columbia (Labour Relations Act, B.C. REv. STAT. c. 205 (1960), \& (10(4)), and elsewhere, although $a$ union may be certified for a multi-employer bargaining unit, the consent of each employer affected is required for inclusion in the unit. Moreover, for purposes of a strike vote, the unit is fragmented into a number of single-employer constituencies, in each of which a majority vote is a necessary prerequisite of a legal strike. See Association of Electrical Contractors V. I.B.E.W. (1963) 40 D.L.R.2d 907 (Alta. S.C.); Pacific Western Planing Mills v. I.W.A., [1955] 1 D.I.R. 652 (B.C.S.C.).

6 See, e.g., Labour Relations Act, ONT. REV. STAT. c. 202 (1960), § 12; B.C. REv. STAT. c. 205 (1960), \$ 18. This duty, of course, embraces conciliation.

7 See Inter alia, Arthurs, Tort Liability for Strikes in Canada: Some Problems of Judicial Workmanship, 38 CAN. B. REv. 346 (1960); Carrothers, Recent Developments in the Tort Law of Picketing, 35 CAN. B. REv. 1005 (1957). 
the former remains virtually unexplored: almost anything satisfies the duty. ${ }^{8}$

The challenge for men of law, as even this brief survey indicates, is to avoid the collision of irresistible social forces and immoveable legal objects.

Consider, first the law as an immoveable object, rigid in both procedure and substance. Two basic, but often clashing, values in the law are speed and fairness. Of course, in industrial relations, time is always of the essence. A union awaiting certification may see its support ebb away over a period of weeks or months; an employer threatened with picket line pressure may lose thousands of dollars in a single day; the relative bargaining strength of the parties may be greatly altered if negotiations are protracted into or beyond peak production periods. Yet, there is always the danger that in attempting to move with the rapid pace of events, legal procedures may be less than fair. Three quite different examples come to mind.

Crucial to understanding the current controversy ${ }^{9}$ over the use of the labour injunction, is realization of the fact that it involves these legitimate but competing values - speed and fairness. The employer's interest is in speed: for him time is money. The union, accused of wrongdoing, takes its stand on the issue of fairness: for it, time is the opportunity to prepare and present a defence. To some extent, the unions' position was vindicated when British Columbia and Ontario both virtually abolished the ex parte injunction, in 1959 and 1960, respectively. ${ }^{10}$ The legislatures apparently decided that confrontation of one's accuser, a basic principle of our legal procedure, was more deserving of protection than speedy protection of an employer's

8 R. ex. rel. Hearn v. Norfolk General Hospital, (1958) 119 Can. Crim. Cas. Ann. 290 (Ont. Mag. Ct.); New Method Laundry and Dry Cleaners, (1957) C.C.H.L.I.R. P. 16,059 (O.L.R.B.); Trenton Memorial Hospital, 64 C.L.I.C. P. 16,302 (O.L.R.B.).

$9 \mathrm{~A}$ number of unions submitted briefs to the Royal Commission on Civil Rights in Ontario (Hon J. C. McRuer, Commissioner) attacking the use of the labour injunction. For example, the SUBMISSION OF THE UNITED AUTOMOBILE WORKERS at 1, suggests that "the labour injunction encroaches unjustifiably upon two of our most basic civil liberties - freedom of speech and due process of law." See generally CARROTHERS, THE LABOUR IN JUNCTION IN BRITISH COLUMBIA (1956); SEIDENBERG, THE LABOUR INJUNCTION IN NEW YORK CITY, 1935-1950 (1953); Aaron, Labor Injunctions in the State Courts, 50 VA. L. REV. 951, 1147 (1964).

10 Trade Unions Act, B.C. REv. STAT. c. 384 (1960), § 6; Judicature Act, ONT. REV. STAT. c. 197 (1960), § 17. 
economic interests. This statement is, however, subject to important qualifications, at least in Ontario. First, violence, destruction of property and disruption of a public service are all enjoinable without notice. ${ }^{11}$ These are, no doubt, reasonable exceptions. Second, only in "labour disputes" is the use of the ex parte injunction restricted. ${ }^{12}$ By a process of judicial interpretation, the term "Iabour dispute" has been confined to situations where there is a proximate employer-employee relationship. ${ }^{13}$ Thus, secondary picketing, organizational and recognition picketing, and other common union tactics, lie beyond the protection of a full hearing. Third, even in cases where notice is given to the offending union, it is frequently a practical impossibility for the union to avail itself of its theoretical privilege to file affidavit material, and to cross-examine the employer's witnesses. ${ }^{14}$ Thus, the injunction may be decided on the basis solely of material filed by the plaintiff employer. Fourth, injunction matters are heard in weekly court, where often a list of thirty or forty cases threatens to engulf the most dedicated judge; the time available for a full canvass of the relevant facts and law may be severely limited. Finally, restrictions upon the right to appeal from interlocutory injunction orders means that the jurisprudence developed by the trial courts has never been thoroughly rationalized by appellate review, at least in Ontario..$^{15}$ All of these facts give to labour injunction proceedings an air of unseemly haste. Yet the challenge is clear: if there is wrongful picketing being conducted, with severe financial losses being inflicted upon the employer, is he not entitled to speedy relief?

Other jurisdictions have grappled with this problem, and have not always resolved it satisfactorily. In England, for example, judicial regulation of industrial disputes was all but ended by the Trade Disputes Act of $1906,{ }^{16}$ which immunized unions from

11 Judicature Act, ONT. REv. STAT. c. 197 (1960), § 17 (3).

12 Judicature Act, ONT. REv. STAT. c. 197 (1960), $\$ 16,17$.

13 Cf. Poole Construction v. Horst, (1964) 47 D.L.R.2d 455 (Sask. C.A.). There are no reported Ontario decisions on this point.

14 Rules of Practice, ONr. REv. REG. 1960, Reg. 396, § 228 (right to give evidence on motion by affidavit); $\$ 229$ (right to cross-examine deponent); $\$$ 230 (right to have witness attend to give evidence upon a motion).

15 Hersees of Woodstock v. Goldstein [1963] 2 Ont. 81 (C.A.) is the only reported picketing case to have reached the Ontario Court of Appeal since 1934. For an illustration of the extreme reluctance of the courts to grant leave to appeal, see Robertson-Yates v. Fitzgerald, (1965) 50 D.L.R.2d 509 (Ont. H.C.)

16 Trade Disputes Act, (1906) 6 Edw. VII, c. 47. 
most of the causes of action upon which injunctions might be based. Whether recent developments in the English law will lead to a resurrection of the labour injunction in the country of its birth, remains to be seen..$^{17}$ In the United States, labour board orders, enforceable in the courts, have displaced the injunction as we know it. ${ }^{18}$ Indeed, since 1932 the federal courts of the United States have been explicitly forbidden to issue labour injunctions in all but the most extreme circumstances, and after compliance with carefully stipulated procedural safeguards. ${ }^{19}$ Some say that the labour board relief is too slow. But is it necessarily beyond the ingenuity of lawyers to strike a reasonable balance between the demands of fairness and those of speed? Surely not. But it will not be done by slogan-mongering or academic rumination. We need a thorough statistical analysis of present practices and their consequences. ${ }^{20}$ Only with this background of factual information can we lift the search for better techniques above the parochial demands of the parties for arrangements which will most favour their respective positions.

Another interesting procedural problem relates to the introduction of notorious facts into the record in labour litigation. A well-established doctrine of evidence, called "judicial notice," permits the judge to take account of notorious facts to supplement the evidence on the record. ${ }^{21}$ The problem is, of course, what facts are notorious? For example, in Smith Bros. v. Jones, $\mathrm{Mr}$. Justice McLennan took judicial notice of the fact that "the development of the Trade Union movement has reached the point where workers will not cross the picket line to go to

17 Hoffman, Rookes v. Barnard, 81 L.Q. REv. 116 (1965), cites to the extensive writing in English periodicals on that case. See also Wedderburn, Intimidation and the Right to Strike, 27 MOD. L. REV. 257 (1964); Christie, Comment, Industrial Relations - Torts - Intentional Interference With Advantageous Trade Relationsbips, 42 CAN. B. REV. 464 (1964); Carrothers, Order Into Cbaos: The Case of The Intransigent Draughtsman, 2 U.B.C.L. Rev. 270 (1965).

18 National Labour Relations Act, 29 U.S.C., Chap. 7, \$ 160 (e); 49 Stat. 449, am. 61 Stat. 136,73 Stat. $519 \$ 10(\mathrm{e})$.

19 Norris-LaGuardia Act, 29 L'.S.C., Chap. 6, $\$ 107$ et. seq.; 47 Stat. 70, $\$ \S 7$ et. seq.

20 For a pioneering effort in Canada, see CARROTHERS, op. cit. supra note 9; Carrothers, The British Columbia Trade-Unions Act, 1959, 38 CAN. B. REv. 295 (1960). American studies both prior to and subsequent to Dean Carrothers' book have been invaluable in this regard; see Seidenberg, op. cit. supra note 9, Aaron supra note 9, and FRANKFURTER \& GREENE, THE LABOUR INJUNCTION (1930).

21 Schiff, The Use of Out-of-Court Information in Fact Determination at Trial, 41 CAN. B. REv. 335 (1963). 
work."22 In Hersees of Woodstock v. Goldstein, Mr. Justice Aylesworth was prepared

to take judicial notice that the rule [of respect for the picket line] affects as well, many other members of the public who are not employees ... particularly where, as at the case at bar, there is a widespread organization of labour. ...23

Finally, in Heather Hill Appliances v. McCormick, Mr. Justice Stewart judicially noted that

a high percentage of unions are dominated by persons from another State whose basic concepts of law, order, good conduct and labour relations are not necessarily ours, but whose control seems to be absolute.24

His judgment is replete with a variety of amusing and fanciful similes which involve judicial notice as well: management "a long time ago" is characterized as an "unregenerate Scrooge";"25 a picket line is analogized to "an electric fence" which is said to likewise seem "harmless enough"; ${ }^{26}$ and unionists are characterized as "true believers" who will refuse to cross picket lines as "a matter of faith and morals and an obligation of conscience." 27 These few illustrations demonstrate that the courts do not hesitate to supply social data where they think it necessary, by means of judicial notice, even as to such critical matters as the impact of a particular picket line upon a particular employer. They should not necessarily be criticized for doing so; it is worthy of serious admiration that men so remote from industrial conflict should be so steeped in its folklore.

On the other hand, the Labour Board, which is presumably staffed by experts in the field of industrial relations, has occasionally been chastised for engaging in a similar practice of officially noting notorious facts of industrial life. Thus, in the Tange Company case, ${ }^{28}$ the Ontario Labour Relations Board was held to have legally misconducted itself by reason of taking official notice of its own earlier finding that the Christian Labour Association discriminated on religious grounds against prospective nonChristian members, and was thus ineligible for certification. The case is important, because it demonstrates against the ever-

22 Smith Bros. Construction v. Jones [1955] 4 D.I.R. 254 at 264.

23 [1963] 2 Ont. 81 at 85 (C.A.).

24 (1965) C.C.H.L.L.R. P. 14,083 (Ont. H.C.) (An appeal to the Ontario Court of Appeal, as yet unreported, has been dismissed).

25 Supra note 25 at 11,364 .

$2 B$ Ibid.

27 Ibid.

28 Tange Co. Itd, (1961) C.C.H.L.L.R. P. 16,225 (O.L.R.B.), quashed on cert., sub nom. R. v. O.L.R.B., ex parte Trenton Construction Workers [1963] 2 Ont. 376. 
present risk of conflict between speed and fairness. After all, the Christian Labour Association had allegedly changed its policies in the interval and thus could insist on being judged on its present, not its past, practices. Its right to do so is hardly answered by the plea that were the Board obliged to redetermine the status of a union each time it appeared in proceedings, it surely could not function. To be sure, the Board does not always choose speed over fairness. It often seeks full information, and invites the widest range of views, both from the parties and from those who might be affected by the precedent impact of decisions. An example of this is the Board's practice of receiving submissions from local employers and unions before defining geographic areas in construction industry certification cases. ${ }^{29}$ This is a sensible, praiseworthy and thoroughly nonjudicial procedure. The lawyer's task, sometimes well-performed by the Board and sometimes not, is to devise procedures which will allow it to employ its expertise without denying to the parties an opportunity to make a full and effective presentation of their position. ${ }^{30}$

Another illustration of the need of lawyers and legal institutions to develop procedural flexibility is the issue of time limits. The Labour Board Rules, for example, require compliance with a variety of time limits as a condition of contesting certification of a trade union. ${ }^{31}$ Similarly, collective agreements customarily specify time limits within which grievances must be filed and processed at succeeding steps. ${ }^{32}$ It is natural for law-trained personnel to put great stock in time limits: after all, court litigation is likewise riddled with them. However, proceedings before the Labour Board or arbitration boards are frequently initiated, and often conducted throughout, by laymen; employees are key figures. Yet few laymen and even fewer employees have any knowledge of even the rudiments of

29 Fraser-Brace Engineering, (1964) Mar. Mthly. Rep. 660 (O.L.R.B.); W. F. Flynn, (1964) June Mthly. Rep. 112 (O.L.R.B.); see also An Interim Report on Construction Industry Division Ontario Labour Relations Board, (1964) Feb. Mthly. Rep. (O.L.R.B.).

30 See FinkelmaN, THE ONTARIo Labour RELATIONS BOARD aNd NaTURAL JUSTICE, at $40 \mathrm{ff}$. (1965).

31 ONT. REV. REG. 1960, Reg. 401 (as amended), \$§ 6-11.

32 See, e.g., 1962 MASTER AGREEMENT BETWEEN MASSEY-FERGUSON AND U.A.W. \& 606: "A grievance must be filed and appealed within the time limits set forth above or the grievance shall be considered settled on the basis of the last answer given." See also Webster Air Equipment Co. Grievance, 3 Lab. Arb. Cas. 1057 (1952); Kellogg Co. of Canada, 12 Lab. Arb. Cas. 22 (1961). 
the collective agreement or the Labour Relations Act, let alone a sophisticated awareness of the risks of being out of time. Surely, the challenge here is to develop legal rules to distinguish between those breaches of time limits which have a discernibly disruptive effect on the conduct of proceedings, and those which are without prejudice to anyone. It should be observed that both the Labour Board ${ }^{33}$ and courts ${ }^{34}$ are statutorily authorized to make this distinction. Without an authorizing statute ${ }^{35}$ can other industrial relations tribunals meet this challenge of flexibility and informality, when contrary modes of thought and habits of business are deeply ingrained as a result of experience in other kinds of proceedings?

Consider next the inhibiting effect of precedent upon the law's response to challenges both internal and external. Lower courts are generally bound by the past decisions of higher courts, But, because higher courts are involved so seldom in labour relations litigation, most of the governing authority which controls the day-to-day disposition of cases is remote both in time and in outlook from modern labour relations. ${ }^{36}$ The leading tort cases in the field, at least until recently, have been the classic English trilogy, Allen v. Flood, ${ }^{37}$ Quinn v. Leathem, ${ }^{38}$ and Mogul Steamship v. McGregor ${ }^{30}$ These cases, decided by the House of Lords at the turn of the century, are based upon a suspicion of concerted labour activity. This suspicion runs directly counter to the assumption in our modern statutes that collective bargaining is an acceptable way of life. Moreover, within a few years of being pronounced, the trilogy was repudiated by the enactment of the 1906 Trade Disputes Act. It is true, of course, that the recent decisions of the House of Lords in Rookes v. Barnard ${ }^{40}$ and Stratford $v$. Lindley ${ }^{41}$ may have "driven a coach and four"42 through the 1906 legislation. Yet

3i Labour Relations Act, ONT. REv. STAT. c. 202 (1960), § 86; B.C. REv. STAT. c. 205 (1960), § 70.

34 Rules of Practice, ONT. REv. REg. 1960, Reg. 396, $\$ \$ 178,186$.

35 It might be argued that the Ontario Labour Relations Act, section 86 , which purports to apply to all "proceedings under this Act" extends as well to boards of labour arbitration which have been characterized as "statutory tribunals" in Ontario: Re International Nickel \& Rivando, [1956] Ont. 379 at 386 (C.A.).

36 Arthurs, supra note 7.

37 [1898] A.C. 1.

38 [1901] A.C. 495.

39 [1892] A.C. 25.

40 [1964] 1 All E.R. 367 (H.L.)

41 [1964] 3 All E.R. 102 (H.L.)

12 Christie, supra note 17. 
for fifty years or more, the English caselaw, like the English legislation, was marked by judicial reluctance, wise or otherwise, to intervene in industrial disputes. ${ }^{43}$ Indeed, even had the English judges been more active, only by coincidence would. their decisions have paralleled the labour policy marked out by our legislatures. The inevitable task of meshing common law tort doctrines of yester-year with the latest legislation has been undertaken with varying degrees of success by our courts.

Most defensible is a line of cases which appears to measure the common law legality of picketing by its impact upon the statutory scheme of industrial relations. Thus, in Smith Bros. v. Jones ${ }^{44}$ and in Gagnon v. Foundation Maritime, ${ }^{45}$ picketing to secure recognition was proscribed because the statute provided a peaceful and lawful procedure by which unions might gain recognition. The certification machinery was intended to remove recognition as a cause of industrial strife and these cases promote the same objective. Likewise in the Therien case, ${ }^{46}$ failure to resort to the grievance machinery to adjust a dispute over the interpretation of a collective agreement was held to be tortious, because it contravened the statutory policy in favour of arbitration. Again, in the Nipissing Hotel case, ${ }^{47}$ a union was held liable for asserting economic pressure during negotiations, before exhaustion of the conciliation machinery. Such pressure was held to be wrongful because it subtracted from the union's statutory duty to "bargain in good faith". While one may quibble, on the facts of any of these cases, with its outcome, and with the language in which the decision was couched, they represent a useful attempt to integrate statutory policy into the common law.

43 Kahn-Freund, Legal Framework, in FlANDERS \& CIEGG, THE SYSTEM OF INDUSTRIAL RELATIONS IN GRET BRITAIN, at 42 (1960).

44 [1955] 4 D.I.R. 254.

45 [1961] Can. Sup. Ct. 435.

46' Int'l. Bro. of Teamsters v. Therien, [1960] Can. Sup. Ct. 265.

47 Nipissing Hotel v. Hotel \& Restaurant Employees Union, (1963) 38 D.L.R. 2d 675 (Ont. H.C.).

48 Carrothers, Secondary Picketing, 40 CAN. B. Rev. 57 (1962); Arthurs, Labour Law - Secondary Picketing - Per Se Illegality - Public Policy, 41 CAN. B. REv. 573 (1963).

49 Labour Relations Act, ONT. Rev. STAT. c. 202 (1960), § 57: "(1) No person shall do any act if he knows or ought to know that, as a probable and reasonable consequence of the act, another person or persons will engage in an unlawful strike or an unlawful lockout. (2). Sub-section 1 does not apply to any act done in connection with a lawful strike or lawful lockout."

50 See Laskin, The Ontario Labour Relations Amendment Act, 1960, 14 U. TORONTO I.J. 116 (1960); also (1960), 2 ONT. LEGISL. Ass. DEB. at 21072115. 
On the other hand, there are certainly many cases in which the courts have acted totally without reference to statutory guidelines. This has been most dramatically demonstrated in the law of secondary picketing. ${ }^{48}$ Here, it seems, they have given way to the temptation to make judicial policy out of whole cloth, rather than to merely stitch up the open seams in a wellmeasured legislative purpose. In Ontario, as in many other provinces, the Labour Relations Act does not regulate picketing. The only provision touching upon picketing at all is section $\mathbf{5 7}$ which forbids the doing of any act which as a reasonable and probable consequence is likely to cause an unlawful strike. ${ }^{49}$ A review of the legislative history of this provision quite clearly indicates that it was an extremely limited incursion into the field of picketing generally, and secondary pressures in particular. ${ }^{50}$ Indeed, it is further limited by the proviso that it has no application to acts done during the course of a lawful strike. Yet, notwithstanding the refusal of the Ontario legislature to outlaw secondary picketing, as recommended in 1958 by its Select Committee on Labour Relations, ${ }^{51}$ the Ontario Court of Appeal has done just that in the Hersees case. ${ }^{52}$ This precedent was followed in a recent Ontario case which forbids so-called secondary picketing by a union, lawfully on strike, at a construction site on which several other unions were engaged. ${ }^{53}$ While the non-picketing unions, by tradition, respect the picket line and thus themselves perhaps engage in an unlawful work stoppage, the saving provision of section 57 is clearly intended to ensure that liability falls upon those who stop work unlawfully, and not upon the picketers. But much more significant than the failure to appreciate the rather obscure legislative policy towards picketing is the continued and flourishing development of a body of tort doctrine totally without regard to legislative policies. The case referred to may effectively prohibit all picketing in the construction industry since inevitably several unions are present on a single job site.

The problem, put shortly, is that the courts have not learned the language of contemporary industrial relations. In this day and age to echo precedent, to talk of inducing breach of contract, of conspiracy to injure, of nuisance, and of other choice items in

\footnotetext{
5L SELECT COMMITTEE ON LABOUR RELATIONS OF THE ONTARIO LEGISLATURE, at 41 (1958).

52 [1963] 2 Ont. 81 (C.A.).

53 Robertson-Yates v. Fitzgerald, (1965) 50 D.L.R.2d 509.
} 
the judicial "vocabulary of vituperation," total lack of understanding of the union tactics against which these doctrines are mobilized. Of course, some of these union tactics are objectionable; some are not. But all too often, there is simply no investigation of their validity. If the tactic falls into one of the traditional tort pigeon-holes, it is outlawed without further ado. This mechanical jurisprudence, this refusal to engage in realistic decision-making, is an almost inevitable by-product of reliance upon precedent. Yet, after all, precedent is the style of the common law. May it be, then, that the courts will never be able to respond to the challenge of moulding the common law to changed circumstances and policies, absent clear legislative instructions?

One is little reassured by the brave words of an Ontario judge in a recent case. ${ }^{55}$ In granting, for the first time, an anticipatory or quia timet injunction, Mr. Justice Stewart remarked:

I have not been cited any cases in which a quia timet injunction has been granted in labour matters nor have I been able to find any authorities myself. However, problems presented by new situations or by strange concatenations of circumstances have never been found insuperable by the law and, indeed, the genius of the common law has always been that remedy should follow need and that formalism never stultify justice. Nor, as has been said can equity be prescribed to be beyond the age of childbearing. 56

The other side of the argument was put eloquently by a great American jurist, Mr. Justice Brandeis:

The unwritten law possesses capacity for growth; and has often satisfied new demands for justice by invoking analogies or by expanding a rule or principle. This process has been in the main wisely applied and should not be discontinued. Where the problem is relatively simple, as it is apt to be when private interests only are involved, it generally proves adequate. But with the increasing complexity of society, the public interest tends to become omnipresent; and the problems presented by new demands for justice cease to be simple. Then the creation or recognition by courts of a new private right may work serious injury to the general public, unless the boundaries of the right are definitely established and wisely guarded. In order to reconcile the new private right with the public interest, it may be necessary to prescribe limitations and rules for its enjoyment; and also to provide administrative machinery for enforcing the rules. It is largely for this reason that, in the effort to meet the many new demands for justice incident to a rapidly changing civilization, resort to legislation has latterly been had with increasing frequency. ${ }^{5 i}$

In labour matters, Brandeis' prophecy of fifty years ago has proved sound. Today, Canadian labour tribunals exercise broad

54 Fraser v. McKernan, (1931) 40 Commw. L.R. 343 at 410 (Aust. H.C.) (Evatt, J.).

55 Foundation Co. v. McGloin, (1964) 42 D.I.R.2d 209 (Ont. H.C.).

$56 \mathrm{Id}$. at 211 .

57 International News Service v. Associated Press, 248 U.S. 215 at 262 (1918); cf. McRuer, C.J.H.C., in Dewar v. Dwan, [1957] Ont. 546 at 548. 
remedial jurisdiction: simple and non-enforceable declarations, ${ }^{58}$ orders of reinstatement and compensation, ${ }^{59}$ elaborate and potent remedies such as cease and desist orders ${ }^{60}$ and orders to dissolve a dominated labour organization. ${ }^{61}$

So long as the men who administer these tribunals are competent and dedicated men, and so long as their procedures are fair, within the limitations of fast-moving problems, there should be no objection to this trend. However, many lawyers and laymen, well-intentioned but poorly-informed, possess an exaggerated and wholly unwarranted faith in the judges as creative lawmakers and as the sole guardians of due process. Their crusading zeal may yet subvert and destroy the immensely successful administrative tribunals which have grown up over the past half-century. ${ }^{62}$

No less difficult than the internal adjustments of legal institutions are the challenges posed by the irresistible social forces in the world around us, a world platitudinously described above as undergoing a "revolution of expectations." One obvious symptom of this revolution is the increasing frequency with which society intervenes in disputes which are said to affect the public interest.

By any definition, disputes in public utilities, in transportation system, and in hospitals would fall within the ambit of the public interest. In each of these fields, the public has intervened in Canada in recent years, through legislation to forestall strikes by substituting a process of compulsory arbitration. ${ }^{63}$ But how broadly should we define the public interest? Where does this intervention end? The United States government appears to have become an uninvited camel in the collective

5\& Labour Relations Act, ONT. REv. STAT. c. 202 (1960), \$\$ 67, 68.

59 Labour Relations Act, ONT. REv. STAT. c. 202 (1960) $\$ 65$.

60 Labour Relations Act, B.C. REv. STAT. c. 205 (1960), \$ 7(4); Trade Union Act, SASK. REv. STAT. c. 259 (1953), \& 5(e); Trade Union Act, N.S. REv. STAT. c. 295 (1954), \& 40(4).

61 Labour Relations Board Rules and Regulations, SASK. O.C. 1233/47 (as amended), clause 5; Labour Code, QUE. REV. STAT. c. 141 (1964), § 132.

62 It is noteworthy, however, that the REPORT OF THE COMMITTEE ON THE ORGANIZATION OF GOVERNMENT IN ONTARIO (1959) which recommended "as a guiding principle that rights of appeal [from administrative tribunals] should be facilitated wherever possible" (p. 24), also warned of the "great harm" inherent in "prolonging the proceedings" in labour matters, and exempted the Labour Relations Board from this recommendation (p. 25).

63 See, e.g., Railway Operations Continuation Act, CAN. STAT. c. 2 (1960); Ontario Hydro-Employees Union Dispute Act, ONT. STAT. c. 94 (1961-62); Toronto-Hydro Employees Union Dispute Act, ONT. STAT. c. 131 (1965); Hospital Labour Disputes Arbitration Act, B.C. STAT. c. 48 (1965). 
bargaining tent of the American steel industry, gradually nudging the parties from the privacy of their conference room into the hard cold light of public scrutiny, gradually substituting for labour-management consensus a government-coerced decree. ${ }^{64}$ In Toronto, the strikes several years ago of the Royal York Hotel, and last year of the city's newspapers, were generally viewed as community crises. In both cases the government intervened, once sucessfully, once unsuccessfully. But it is important to note that this intervention was informal. The legal framework of bargaining has remained unresponsive to this challenge, except where community consensus is overwhelming, as in the case of public utilities, hospitals and railways. Even here we have not responded with the imagination and flexibility that the problem deserves. Assuming that we wish to solve such disputes, if we can, by a process of collective bargaining, then it is evident that any statutory solution ought to maximize the pressures for bargaining, while safeguarding the public against the potential harmful results of a breakdown in negotiations. ${ }^{65}$ Instead, we have simply substituted arbitration for strikes, and we have thereby seriously impaired the calibre of collective bargaining. Indeed, there is every reason to believe that with arbitration as its terminal point, bargaining, as we know it in industry generally, will cease to exist in these special situations. Might it not be preferable to introduce an element of uncertainty, of flexibility, into the settlement of these disputes, in order to preserve some of the vitality of the bargaining process? For example, the Slichter Law in Massachusetts ${ }^{60}$ provides a choice of procedures in situations where industrial disputes threaten the public interest. While most of these procedures have their counterpart in one Canadian statute or another, the full range is available under a single act only in Alberta and Quebec. ${ }^{67}$

64 It should be noted, however, that the most recent example of government intervention, during the 1965 bargaining crisis, involved moral suasion rather than legal compulsion, despite past resort to the emergency disputes provisions of the Taft-Hartley Act.

65 ROYAL COMMISSION REPORT ON COMPULSORY ARBITRATION IN DISPUTES AFFECTING HospitAls AND TheIR EMPLOYEes (Ontario, 1964) at 47: "The problem then ... is how to preserve for the sake of the hospitals, the unions and the public, the value of free collective bargaining and at the same time ensure that hospitals will be kept open to maintain satisfactory patient care under conditions which will not be detrimental to either management or its employees ..."

66 MASS. STAT. c. 150B, § 2, as am. by c. 596 L. 1947.

67 Alberta Labour Act, Alta. Rev. Stat. c. 167 (1955), § 99 (as am. Alta. STAT. c. 54 (1960); Labour Code, QUE. REV. STAT. c. 141 (1964), § 99 (as am. QUE. STAT. c. 50 (1965)). 
Of course, in the sense that ad hoc legislation, rather than preestablished procedures, has been the Canadian approach, technically the government of the day has an unlimited choice of procedures. But ad hoc legislation does have two disadvantages: it cannot quickly be enacted, and it brands one party with a stigma of irresponsibility which further inhibits bargaining. Of course, one alternative to such legislation would be encouragement of institutional arrangements, on the Scandinavian model, ${ }^{68}$ which reduce the incidence of strikes by improving the calibre of bargaining.

A problem of broader dimensions, but lesser intensity, is that of technological or corporate change during the lifetime of the collective agreement. Sometimes, an employer may make such changes expresly in order to subvert the bargaining relationship. Sometimes, the changes are normal responses to competitive pressures. Has the law really proved capable of adjusting these clashing interests - the desire for industrial relations stability and the need for managerial flexibility in a competitive economy? The successor rights problem affords an example. It is no secret that some employers have engaged in a form of corporate metamorphosis for the express purpose of shedding their collective bargaining obligations. Particularly in industries such as construction, where the goodwill attaching to a small construction firm is negligible, might an employer conveniently go out of business and emerge under a new corporate charter. In so doing, under the Ontario Labour Board's jurisprudence, ${ }^{69}$ he was able to rid himself of the union which had organized his employees. The Goldenberg Royal Commission, investigating labour relations in the construction industry in Ontario, recognized that this device promoted industrial strife and had no apparent compensating benefit to the industry as a whole. ${ }^{70}$ Accordingly, the Commission recommended amending legislation, which ultimately was enacted. ${ }^{71}$ Whether or not the legislation adopted in On-

${ }^{6}$ Arthurs, Labour Lore and Labour Law: $A$ North American View of The Danish Experience, 12 I.C.L.Q. 247 (1963); GALENSON, THE DANISH SYSTEM OF LABOUR RELATIONS, (1952); JOHNSTON; COLLECTIVE BARGAINING IN SWEDEN, (1962).

69 See, e.g., New Method Laundry \& Dry Cleaners, (1957) C.C.H.L.L.R. P. 16,059 (O.I.R.B.); Brantford Produce, (1961) C.C.H.L.L.R. P. 16,193 (O.I.R.B.).

70 REPORT OF THE ROYAL COMMISSION ON LABOUR-MANAGEMENT RELATIONS IN THE CONSTRUCTION INDUSTRY (Ontario, 1962) at $44 \mathrm{ff}$.

71 The Legislation recommended by the Commission was enacted by Iabour Relations Act. ONT. STAT. c. 68 (1961-62), \$ 4 (never proclaimed in force); replaced by ONT. STAT. c. 70 (1962-63), now \$ 47a. 
tario, and other Canadian jurisdictions, ${ }^{72}$ is really adequate to the task at hand, is a matter of serious controversy. ${ }^{73}$ It is noteworthy, however, that the National Labour Relations Board in the United States - unlike our own labour boards - solved the same problems without legislative assistance. ${ }^{74}$

The related problem of sub-contracting has also been met with a singular lack of imagination and intellectual sophistication by Canadian arbitrators. Again without regard to a contrary American jurisprudence of substantial dimensions, ${ }^{75}$ the trend of the Canadian law has been to permit sub-contracting wherever the work is no longer to be done under the employer's supervision and direction..$^{76}$ Adopting a highly irrelevant test of employment from the law of agency, and prostrating themselves before the doctrine of management rights, Canadian arbitrators have failed to appreciate the potential risks of sub-contracting to industrial peace. Similarly, the "runaway plant" problem has evoked a minimal response from our legislators and labour boards. ${ }^{77}$ The issue is by no means clear, but surely a balance must be struck at some point between an employer's absolute freedom, and the interests of his workers and their union. Where the movement of work is the product of economic pressures, for example, a desire to be nearer markets, suppliers, or transportation, labour relations policies are no more than a neutral factor in evaluating it. It is rather humanitarian concern for employees displaced or left behind which may prompt public intervention. ${ }^{78}$ However, where dislocation or plant removal is motivated by anti-union sentiment, our public policy of promoting collective bargaining has been thwarted. ${ }^{79}$ The runaway plant, or the plant that has displaced its workers to escape unions, is certainly

i2 See, e.g., Labour Relations Act, § 19, MAN. REv. STAT. c. 132 (1954), §§ 10 (1) (d), 18 (1) (c) (as amended); Labour Relations Act, B.C. REV. STAT. c. $205(1960), \S 12 \mathrm{~A}$ (as amended).

is Hamilton Cotton, (1964) June Mthly. Rep. 190 (O.L.R.B.); Dutch Boy Food Markets, (1965) C.C.H.L.L.R. P. 16,051 (O.L.R.B.); Thorco Manufacturing Limited, (1965) C.C.H.L.I.R. P. 16,052 (O.I.R.B.); National Paper Box, (1964) C.C.H.L.L.R. P. 14,002 (B.C.S.C.); Gulf Island Navigation Itd. v. Seafarers International et al., (1959) 18 D.L.R.2d 216 (B.C.S.C.).

74 Wiley v. Livingston, 376 U.S. 543 (1964).

75 See Fibreboard Paper Products v. N.L.R.B., 379 U.S. 203 (1964); Anderson, plant Removals and Subcontracting of Work, 15 LAB. LAw JO. 608 (1964).

${ }^{7} 6$ For a comparison of U.S. and Canadian Developments, see generally YoUNG, THE CONTRACIING OUT OF WORK (1964).

it Amalgamated Electric Corp., (1963) Oct. Mthly. Rep. 403 (O.L.R.B.).

is Plant Relocation and Its Consequences, 65 LAB. GAZ. 702 (1965).

79 Alger Press Ltd., (1964) Sept. Mthly. Rep. 290 (O.L.R.B.); but see R. v. Labour Relations Board (B.C.), ex parte White Lunch, (1963) 42 D.I.R.2d 364 (B.C.S.C.). 
falling below a community standard of conduct as surely as the plant which pollutes a nearby river, or produces a nuisance in a residential neighbourhood. Although control may be difficult, given a "rule of reason" it should not be impossible to ensure compliance with community standards. ${ }^{80}$

Allied to the problem of allocating work as between those in the bargaining unit and those beyond it, is the problem of allocating work as between men and machines. ${ }^{81} \mathrm{~A}$ collective bargaining contract constructs an edifice of classifications and wages upon a foundation of stable and familiar techniques of production. Particularly in mature and sophisticated collective bargaining relationships do the parties evaluate carefully the labour content of jobs, to ensure that remuneration will correspond to effort and skill. Moreover, the seniority clause does not merely protect the older worker for humanitarian reasons; it assumes as well that the senior employee will be more highly skilled and thus better qualified to fill highly paid jobs. This latter assumption is also based upon the continued existence of familiar production patterns. Finally, the very premise of collective bargaining itself assumes a stable rather than a dynamic need for labour; it is the predicted availability of work, or the anticipated effect of a threatened withdrawal of services that ultimately pressures the parties to bring about an agreement during their negotiations. Technological change may shatter this foundation of assumptions and topple the entire legal edifice.

Consider the impact of technological change on the wage and classification structure. The agreement identifies by name a number of jobs. If their content is radically transformed, or their very existence ceases, what wages and classifications are then to apply to the former occupants of those jobs? To foresee all new classifications which might conceivably come into existence during the lifetime of the agreement is an obvious exercise in futility. To forbid the introduction of new machines (and thus of new job classifications) is to place an impossibly high premium on stability, with almost disastrous consequences for the employer's competitive position. Yet to allow the employer freedom to break down old work patterns, is not to say that he must be allowed freedom to erect new ones. If the employer could simply

80 Fibreboard Paper Products v. N.L.R.B., 379 U.S. 203 (1964); Textile Workers Union v. Darlington Manufacturing, 85 S. Ct. 994 (1965).

81 See generally SOMERS, CUSHMAN, WEINBERG (eds.), ADJUSIING To TECHNOLOGICAL CHANGE (1963). 
establish new classifications, he might destroy the fruits of collective bargaining by his unilateral act. By and large, neither the parties nor the law have responded in an imaginative fashion to the challenge of reconciling the employer's freedom to innovate with the regime of collective bargaining. Unions have asked for the right to strike to force the employer to bargain about, and agree upon, new classifications and wages, a right now suspended during the lifetime of a collective agreement. ${ }^{82}$ Employers, on the other hand, are content with the status quo, because the statutory obligation to arbitrate disputes during the period when strikes are forbidden only extends to the interpretation or application of the agreement, and not to the fixing of new wages and working conditions..$^{83} \mathrm{~A}$ compromise, one which has appeal as a reasonable use of a legal mechanism, is to entrust the fixing of new work standards and wages to third party adjudication. This is not to say that such adjudication must in every case take place. Rather, the possibility of arbitration provides an incentive for the parties to resolve their differences by negotiation. There is no inconsistency in stating that arbitration of wage disputes in public services impedes collective bargaining, while it has the opposite effect in disputes involving the reclassification of employees after technological change. In public service disputes there are potentially large gains to be had in arbitration which cannot be won in negotiation, so that one of the parties would rather arbitrate than negotiate; contrariwise, in classification disputes, the new wage rates an arbitrator will likely fix, which may often affect only a few employees, will be only marginally different from the former rates, so that there is an incentive to avoid the time and expense of arbitration. ${ }^{84}$ On this proposal, a double caveat: who will arbitrate and how? Few arbitrators are skilled in job evaluation. Most people with experience and expertise in this field are employed by either unions or management, and are consequently unable to act as neutral arbitrators. The parties and the government have a joint responsibility to begin a programme of recruitment in this highly sensitive, and obviously expanding, area of labour arbitration. As important

82 Labour Relations Act, ONT. REv. STAT. c. 202 (1960), \$\$ 33, 54; BC. REv. STAT. c. 205 (1960), § 46.

83 Labour Relations Act, ONT. REv. STAT. c. 202 (1960), § 34; B.C. REv. STAT. c. 205 (1960), § 22 .

84 This suggestion is corroborated by experience in the garment industry, where collective agreements typically call for arbitration of "prices" (piece-work rates), failing agreement. Arbitration is seldom, if ever, resorted to. 
as the question of personnel is the question of technique. Fixing new wages and work standards is both a more creative and a more technical task than adjudication of contract interpretation disputes. Perhaps the familiar adversary approach to arbitration is inappropriate: the arbitrator, after all, might wish to make his own time and motion studies, and should not be confined to choosing between one of two contradictory results put in evidence by the parties.

However, while arbitration and various consultative devices are extremely useful in reducing the short-run tensions of disruption and displacement through technological change, in the long run the answers will not likely be found either in collective bargaining legislation or indeed in the collective bargaining process. The problem has its genesis in the employment relationship, but is part of a larger social concern. The victims of technological displacement, particularly older workers who cannot adapt to new industrial techniques, represent in two senses a failure of society. In the first place, they reflect a failure of our educational system: we simply have not trained people to be adaptable. Second, they demonstrate a failure of our social security system: we are not yet able to cope with the appearance on the labour market of that largely unmarketable commodity, the unskilled worker. We have not really learned to avoid human spoilage and waste. Responsibility in this area thus lies beyond the narrow labour-management community. The burdens of training and retraining, of job-finding and job-making, cannot be borne by a particular company and union whose resources and horizons are necessarily limited.

The most fundamental impact of technological change has been upon the balance of power at the bargaining table. The brutal, but inescapable, reality of the computer-age strike is that the employer no longer needs to hire striking union members, or even unemployed nonunionists. Now the computer crosses the picket line and "scabs" in the struck plant. This is the lesson of the Toronto newspaper strike and of several refinery strikes. Deprived of their traditional technique of mounting economic pressures - the strike - it can fairly be expected that unions will experiment with other tactics. Some of these - physical violence to persons or property - are so obviously anti-social that they cannot be permitted. The law's response to such violence is predictable (and usually effective) because there is 
wide agreement on the social undesirability of such conduct. A much more acceptable tactic, one much closer to the mainstream of industrial combat, has been the exertion of various forms of secondary economic pressure. Attempts have been made to secure customer boycotts, to persuade suppliers and commercial carriers to sever business relations with the struck employer, and to encourage non-striking employees in allied jobs to cease work. All have some arguable validity in a situation where the mere withdrawal of labour, the standard bargaining tactic, has virtually no impact. Yet in each attempt, the strikers have been confronted with legal obstacles, some legislative, ${ }^{85}$ others judgemade. ${ }^{86}$ While the law has been inept in resolving the underlying dispute, it has certainly helped to determine the outcome of the strike by preventing various forms of economic pressure. On the one hand, it is possible to simply shrug and say that those who strike against the computer are in the same position as any weak union, and had best accept the realities of that position. On the other hand, this counsel of despair is an admission of the willingness to contemplate the ultimate breakdown of collective bargaining, as we know it, in many areas of industry. However, the law could be changed to permit the union to launch countervailing pressures which would to some extent offset the advantages of the computer. In other words we might shift the contest from the labour market, where it is no longer meaningful, to the consumer market where the parties are more evenly matched, by making legal certain forms of secondary pressure which are not now permitted. Because such a legal development is unlikely, unions will probably seek instead to redress the balance of power by altering their structure so as to embrace a wider range of employees, not all of whom would be pitted against the computer in competition for work. Thus, in the newspaper industry, an industry-wide union, whose members gather news as well as print it, would not have been subject to the same pressures as the much more narrowly-based craft union. Yet even if the balance of power is restored, the underlying problem will remain unresolved: who will bear the cost of human obsolescence?

85 Secondary picketing is proscribed in British Columbia: Trade-Unions Act, B.C. REv. STAT. c. 384 (1960), \& 3; and in Newfoundland: Labour Relations Act, NFLD. REv. STAT. c. 258 (1952), (as amended), \$ 43A.

86 See Carrothers and Arthurs, supra note 48: Heather Hill Appliances v. McCormick, (1965) C.C.H.L.L.R. P. 14,083 (Ont. H.C.). 
The prospect of change in union structure poses another critical question. Is it possible - or desirable - to reshape the labour movement by compulsion of law to meet the revolutions of our times? By way of example, consider once again our revolution of expectations. More and more we are coming to expect of our union movement a level of responsibility, integrity, democracy, and social consciousness, which would make it an institutional refutation of the doctrine of original sin. Can the law guarantee our expectations? Obviously, legislation can do much to stop overt forms of undesirable behaviour. The Landrum-Griffin Act in the United States, ${ }^{8 \pi}$ with its Bill of Rights for Union Members, makes legally enforceable the right to democracy and honesty in union administration. In response to a generally less urgent situation, ${ }^{88}$ a number of scattered provisions have appeared in Canadian labour legislation which seek the same end. ${ }^{89}$ Overt forms of racial and religious discrimination, recently forbidden in the United States, have for many years been outlawed in Canada. ${ }^{90}$

It is important not merely to state the undeniable fact that law may have some influence, but also to analyse more precisely exactly what that influence is. Obviously, law acts as a deterrent. Yet equally important is the educative role of law; by a public declaration of the standards of conduct which we expect, many will be led into voluntary, indeed willing, compliance. As a sage has remarked, "many a man has become a good man as a result of a life of hypocrisy." Thus, by continually doing what is expected of us, even without a deep belief in the conventional morality, we may gradually come to believe in its validity. ${ }^{91}$ On the other hand, even the most vigorous programme of enforcement cannot overcome widespread public indifference or hostility to the law's objectives. The prohibition era proved this. Thus, it is important that any law directed towards shaping the

87 Labour-Management Reporting and Disclosure Act of 1959, 73 Stat. 519.

88 The major exception to this generality, the Seafarers International Union, is discussed infra.

80 See, e.g., Ontario Labour Relations Act, ONT. REv. STAT. c. 202 (1960), $\$ \S$ 60-63; British Columbia Labour Relations Act, B.C. REV. STAT. c. 205 (1960) $\S \S 66,66 A$; Alberta Labour Act, $\$ \$ 105-107 A ;$ Newfoundland Trade Union Act, NPID. STAT. c. 59 (1960). Except for the Newfoundland statute, this legislation largely involves reporting and disclosure of union financial statements.

90 See, e.g., Ontario Human Rights Code, ONT. Stat. c. 93 (1961-62), § 4 (originally Fair Employment Practices Act, ONT. STAT. c. 24 (1951)).

91 Cox, The Duty to Bargain in Good Faith, 71 HARv. L. REv. 1401 at 1439 (1958). 
destiny of the labour movement be enacted with the assistance and participation of those most directly concerned. The vast majority of Canadian labour leaders are firmly committed to democracy and honesty, and they ought to be invited to help make laws which would apply to the tiny minority that are not. Because there is a natural and justifiable fear that those outside the house of labour do not always possess a sympathetic understanding of its tenants, so far as possible the enforcement of such laws should also be an internal matter. The Public Review Board of the United Automobile Workers is an excellent model of non-governmental, union-created machinery which can and should be utilized in any systematic approach to regulating the internal affairs of labour unions. ${ }^{92}$

But when we turn from the more obvious dangers of "bossism" to the much subtler questions of union structure and organization, law may well be too crude an instrument to accomplish our purposes. Parliament imposed trusteeship upon the S.I.U. and the other maritime unions. ${ }^{93}$ While the trusteeship has not yet ushered in the millenium in organizational purity, it has curbed the worst abuses of power. Yet, the Trustees have been totally unable to execute their task of welding the various maritime unions into a single effective organization. ${ }^{94}$ Moreover, even in the internal reform of the S.I.U., the Trustees have been compelled to acknowledge institutional realities and loyalties, which have produced the reelection to office of most of the officials of the former regime. Government is obviously not powerless to control one of the most important private institutions in our society, but it can do so most effectively if it operates by example and exhortation, rather than by command. Austin's sovereign did not reign over a pluralistic society. Consider, for example, how government might encourage a more highly centralized labour movement. By government invitation, various central labour bodies could be given an important role in economic forecasting, legislative revision, and consultation in policy planning, which would greatly enhance their importance vis-a-vis their

92 Stieber, Oberer \& Harrington, "Report to the Center for the Study of Democratic Institutions," DEMOCRACY AND PUBLIC REviEW (1960), at 64: "If review were to spread to other unions, it would not create a dynamic labour democracy out of thin air, but it would be an institutional reform of real significance for the ideal of a free society."

93 Maritime Transportation Unions Trustees Act, CAN. STAT. c. 17 (1963).

94 REPORT OF INDUSTRIAL INQUIRY COMMISSION ON THE DISRUPTION OF SHIPPING (Hon. T. G. Norris, Commissioner) at 305 (1963). 
affiliates. ${ }^{95}$ Industry-wide bargaining likewise emphasizes the authority of central labour bodies. Therefore, when government itself bargains, it clearly ought to insist on centrally organized, rather than autonomous, union negotiators on the other side of the table. ${ }^{.6}$ And when collective bargaining takes place in the normal way between employers and unions, government leadership can give great impetus to industry-wide negotiations. That the attempt in the Ontario construction industry, following the Goldenberg Commission Report, to conduct such negotiations under government auspices was unsuccessful, should not foreclose the experiment for all time. ${ }^{97}$ However, a law which compels the dissolution or merger of unions, ${ }^{98}$ which compels their affiliation or non-affiliation with national or international groups, ${ }^{99}$ is an unwarranted interference with a basic civil liberty - freedom of association - which would not seem to be justified by any labour relations crisis in the recent past or present. One could similarly stigmatize the 1961 British Columbia legislation outlawing political activity by Iabour unions. ${ }^{100}$ Quite apart from any questions as to constitutionality, ${ }^{101}$ the legislation represents a failure to come to grips with the basic issues in union political activity. To explain the prohibition of such activity as protection of the right of union members to refrain from coerced political activity ${ }^{102}$ is cynical: any one of a number of lesser restraints could have secured this important goal. To explain the prohibition as an attempt to confine unions to their "proper" function as collective bargaining agents ${ }^{103}$ is question-begging: unions have been engaged in both legislative lobbying and direct political action almost since their inception. ${ }^{104}$ Surely it would have

95 Arthurs, sapra note 68 at $250 \mathrm{ff}$.

96 For example, in the recent strike of postal employees, no single, national organization spoke for the strikers.

97 An account of the conference is contained in WINKLER, A STUDY OF LABOUR RELATIONS IAW IN THE CONSTRUCTION INDUSTRY IN ONTARIO (1964, Unpublished LL.M. Thesis, Osgoode Hall Law School).

98 Trade Union (Emergency Provisions) Act, NFLD. STAT. c. 2 (1959).

99 See Forsey, The Prince Edward Island Trade Union Act, 1948, 26 CAN. B. REv. 1159 (1948).

100 B.C. STAT. c. 31 (1961), \$ 5 (now Labour Relations Act, B.C. Rev. Stat. c. $205(1960), \S 9(6)$.

101 All such questions were decided favourably to the legislation in Oil, Chemical \& Atomic Workers v. Imperial Oil, [1963] Can. Sup. Ct. 584. But see Comments, 22 U. OF TORONTO FAC. L. REv. 161 (1964); 3 O.H.L.J. 203 (1964).

102 Oil, Chemical \& Atomic Workers v. Imperial Oil, supra note 101 at 593, 596 (Martland, J.).

103 Id. at 608 (Ritchie, J.).

104 As early as 1874, a member of the Ontario legislature was elected as a "Workingmen's Candidate." See FRENCH, FAITH, SWEAT AND POLITICS (1962). 
been possible to protect the dissentient union member by allowing those who favour political action to "opt in" by specifically authorizing the deduction of political contributions. As well, the legislation might have forbidden discrimination in administration of the collective agreement or in enjoyment of union membership on the grounds of political neutrality or non-neutrality. If the statute was simply a response to the plight of the dissentient employee, it was an inappropriate response: the legislature wielded a sabre instead of a scalpel.

A recurring theme in this long and discordant fugue of challenge and response is the need for effective techniques of lawmaking. By what process can legal institutions and rules be made to respond more quickly and effectively to the challenges of industrial relations? This is a crucial question, for it is the way in which law is made, as much as its content, that determines its effectiveness.

One need not apologize for seeking the answer in the experience of Scandinavia, an experience that has been characterized by a high degree of success, by a deep commitment to democracy, and by frequent experimentation to meet the changing demands of the industrial environment. The key to law-making in Scandinavia is the full and active participation of labour and management. ${ }^{105}$ Characteristically, legislation there is passed at the joint request of labour and management, to implement policies agreed upon between them. An active role in the administration of legislation is assigned to the central labour and management federations. ${ }^{106}$ Often, indeed, their consensus makes legislation unnecessary, and they live under a form of private self-government. ${ }^{107}$ What we should import from Scandinavia is not the detail of its system, but this central, sensible concept of labour and management participation in the process of law-making. To secure this participation we should establish a labour law commission, a sort of industrial parliament, in which would be gathered unionists and businessmen, lawmakers and academics. Its concern would be an ongoing examination of existing poli-

105 See generally Arthurs, supra note 68; GALENSON, JOHNSTON, op. cit. supra note 68 .

106 For example, only the central federations have a right of audience before the Danish labour court.

107 The substantive legal framework of industrial relations (comparable to our Labour Relations Act) in both Denmark and Sweden is a "Basic Agreement," entered into in 1899 and 1938, respectively, between the central labour and management federations of each country. 
cies, a reasoned exploration of new proposals, and outspoken support for legislation and institutions which intelligent men of good faith could accept as the reasonable compromise between divergent interests. The term "parliament," of course, has a double connotation. The French word "parlement" originally described a chamber of discussion. (Indeed, some would say that this description is equally apt today.) This labour law commission has an important function as a chamber of discussion. At the moment, there is no neutral ground upon which labour, management, public officials, and the academic community, can meet regularly. There are few occasions, beyond the crises produced by collective bargaining, or controversial legislative proposals, for the exchange of views. Thus, there is no accumulation of a fund of goodwill that stems from familiarity and respect, upon which the parties may draw in difficult times. There is much to be said, therefore, for a chamber of discussion. But "parliament" in our contemporary sense is primarily a legislative body. In a special way, this industrial parliament should legislate, as well. Naturally, it must not usurp the functions of the duly elected legislators. However, a measure which had been carefully examined, and approved, by such a representative body would likely muster the necessary parliamentary majority without difficulty. Once enacted, moreover, laws would more effectively command the obedience of all concerned, because of the pre-commitment to legislative policy by well-known unionists, business leaders, and disinterested critics. Another important function of the industrial parliament would be to give the kind of expert and detailed attention to legislation which is so difficult to obtain within the machinery of government. For this purpose, the industrial parliament should be supported by a "civil service" of economists, lawyers, sociologists, industrial management consultants, and labour staff members, recruited and mobilised under the auspices of the universities.

Finally, and perhaps in the far distant future, one can envisage voluntary adherence by labour and management to the standards of behaviour enunciated by the industrial parliament. In securing this voluntary adherence, the pre-eminence of the representative members would be of obvious importance.

No doubt this system of law-making will appear to many to be hopelessly visionary. It is premised on the existence of repre- 
sentatives who can speak with some authority for the parties - a premise very much at odds with our present anarchy of autonomous union and management decision-makers. But to return to an earlier analogy, economic and military coalitions and supra-national authorities are breaking down long-cherished traditions of nationalism. Today's problems are to swift-moving, today's solutions too complex, today's failures too costly, for countries to spurn the international forum provided by the United Nations. The same considerations may produce effective participation in an industrial parliament.

But whatever may come of this proposal, the hope for more effective responses to the challenges of industrial relations lies largely in the creativity of lawyers. As Professor Archibald $\mathrm{Cox}^{108}$ so eloquently remarked in a speech entitled "Lawyers and Social Ferment":

Even in a time of ferment and necessary social change - especially in such a time - the most important thing about the legal profession is that we inherit the tradition of seven or eight centuries of continuous concern for the institutions and aspirations - for the processes, ideals and sense of right and justice - that make for free and civilized society .... Our own era has urgent need for lawyers not to resist change but to channel the vital forces at work in the community along the lines of justice and reason, on a scale and at a pace heretofore unprecedented. Only thus can we fulfill our ancient heritage. . .109

A lawyer, a member of a profession centuries old, who is also a student of industrial relations, a discipline whose existence can hardly be measured in decades, can ask for no more than a vital interaction between the law and the industrial relations community. Each must work its magic upon the other so that the older discipline will be rejuvenated, and the younger brought to maturity.

108 Sometime Solicitor-General of the United States, now Professor of Law, Harvard Iaw School.

109 Address to Hastings College of Law, University of California, reprinted in (1965) HARVARD LAW SCHOOL BUIIETIN 6. 